\title{
Do differences in religious affiliation explain high levels of excess mortality in the UK?
}

\author{
Kevin Ralston, ${ }^{1}$ David Walsh, ${ }^{2}$ Zhiqiang Feng, ${ }^{3}$ Chris Dibben, ${ }^{4}$ Gerry McCartney, ${ }^{5}$ \\ Dermot O'Reilly ${ }^{6}$
}

'National Centre for Research Methods, University of Edinburgh, Edinburgh, UK ${ }^{2}$ Glasgow Centre for Population Health, Glasgow, UK ${ }^{3}$ School of Geosciences, University of Edinburgh Edinburgh, UK

${ }^{4} U$ niversity of Edinburgh Edinburgh, UK

5NHS Health Scotland, Glasgow, UK

${ }^{6} S$ chool of Medicine, Dentistry and Biomedical Sciences, Queen's University Belfast Belfast, UK

\section{Correspondence to}

Dr David Walsh, Glasgow Centre for Population Health, Olympia Building, 2-16 Orr Street, Bridgeton Cross, Glasgow G40 20H,UK; david.walsh.2@ glasgow.ac.uk

Received 1 August 2016 Revised 20 December 2016 Accepted 11 February 2017 Published Online First 7 March 2017
CrossMark

To cite: Ralston K, Walsh D,
Feng Z, et al. J Epidemiol
Community Health
2017;71:493-498.

To cite: Ralston K, Walsh D, Community Health

2017:71:493-498.
ABSTRACT

Background High levels of mortality not explained by differences in socioeconomic status (SES) have been observed for Scotland and its largest city, Glasgow, compared with elsewhere in the UK. Previous crosssectional research highlighted potentially relevant differences in social capital, including religious social capital (the benefits of social participation in organised religion). The aim of this study was to use longitudinal data to assess whether religious affiliation (as measured in UK censuses) attenuated the high levels of Scottish excess mortality.

Methods The study used the Scottish Longitudinal Study (SLS) and the ONS Longitudinal Study of England and Wales. Risk of all-cause mortality (2001-2010) was compared between residents aged 35 and 74 years of Scotland and England and Wales, and between Glasgow and Liverpool/Manchester, using Poisson regression. Models adjusted for age, gender, SES and religious affiliation. Similar country-based analyses were undertaken for suicide.

Results After adjustment for age, gender and SES, all-cause mortality was $9 \%$ higher in Scotland than in England and Wales, and 27\% higher in Glasgow than in Liverpool or Manchester. Religious affiliation was notably lower across Scotland; but, its inclusion in the models did not attenuate the level of Scottish excess all-cause mortality, and only marginally lowered the differences in risk of suicide.

Conclusions Differences in religious affiliation do not explain the higher mortality rates in Scotland compared with the rest of the UK. However, it is possible that other aspects of religion such as religiosity or religious participation which were not assessed here may still be important.

\section{INTRODUCTION}

Despite the well-established links between poverty and poor health, a body of recent research has highlighted high levels of 'excess' mortality (ie, after taking into account differences in socioeconomic circumstances) in Scotland compared with elsewhere in the UK. ${ }^{1-13}$ This has been observed in analyses employing both area-based, and individual, measures of socioeconomic status (SES), and even when controlling for differences in behavioural (eg, smoking, diet) and biological (eg, body mass index, blood pressure) risk factors. For example, analysis of Scottish and English census-based longitudinal data by Popham and Boyle ${ }^{3}$ showed that after adjustment for individual SES, mortality among resident Scots aged 35-74 years was 17\% higher than those in England and Wales. City-based analyses have also demonstrated high levels of such 'excess' mortality for Glasgow (Scotland's largest city) compared with Liverpool and Manchester in England: ${ }^{9}$ despite similar deprivation profiles, premature mortality in Glasgow was shown to be $30 \%$ higher.

A range of hypotheses have been proposed to explain these high levels of excess mortality. ${ }^{12}$ This includes differences in 'social capital', given the evidence linking lower levels of social capital to higher mortality. ${ }^{14-25}$ This has been supported by recent cross-sectional analyses which showed differences in aspects of social capital (trust, reciprocity, social participation) between Glasgow and Liverpool and Manchester. ${ }^{26} 27$ Those analyses additionally highlighted much lower levels of religious affiliation in the Scottish city. This is relevant because of the research evidence around religious social capital: the benefits of social participation in organised religion. Religious social capital has been confirmed as a 'valid construct', ${ }^{28}$ and there is a considerable amount of evidence of the beneficial impact of religious participation on a number of different health outcomes. The latter include many different aspects of mental and physical health ${ }^{29}$ and, importantly for this study, mortality: a 'meta-analytic' review of the evidence in 2000 suggested that higher levels of religious attendance were associated with almost 30\% lower all-cause mortality compared with those with lower levels of participation. ${ }^{30}$ Other reviews have confirmed this association, and although highlighting caveats associated with some of the studies, they have shown that the significantly lower mortality is not explained by important demographic and socioeconomic potential confounders. ${ }^{31} 32$ For example, one study suggested that only $15-20 \%$ of the association between religious participation and mortality was accounted for by such confounding. ${ }^{32} 33$ Recent evidence has also emerged of an independent association between religious involvement and cellular ageing. ${ }^{34}$

Separate research has suggested an important role for religion in impacting specifically on suicide mortality. ${ }^{35-37}$ Suicide has been shown to make a considerable contribution to the high levels of excess mortality observed Scotland and Glasgow. 6913

The aim of this study was to use longitudinal data to assess whether religious affiliation (as well as living alone, another census-based potential proxy for social capital) attenuates the high levels of excess mortality in Scotland (compared with England and Wales) and in Glasgow (compared with Liverpool and Manchester). 


\section{METHODS}

The analyses replicated, and expanded on, the previous research by Popham and Boyle ${ }^{3}$ cited above. We used the Scottish Longitudinal Study (SLS) $^{38}$ (a 5.3\% sample of the Scottish census linked to death registrations) and the Office for National Statistics Longitudinal Study of England and Wales (ONS LS) ${ }^{39}$ (a 1\% sample of the English and Welsh Census, also linked to individual mortality records). Data were again limited to 3574-year-olds (an age group associated with high levels of Scottish excess mortality), born in England and in the ONS LS at 2001, or born in Scotland and in the SLS at 2001. Four measures of SES were used; housing tenure, access to a car/van, economic activity and educational attainment. Individuals were followed from 2001 to the end of 2010. E-DataSHIELD methodology, which combines analysis from discrete sources into a 'joint fit', ${ }^{40}{ }^{41}$ was applied to analyse data: the LS and SLS are 'restricted access' data sets and cannot be removed from site.

E-DataSHIELD is an approach which allows combined analysis of separate data sets where strict security access prevents these data being pooled. DataSHIELD, for generalised linear models, uses iteratively reweighted least squares to produce a 'joint fit' while sharing only the information matrix and score vectors associated with the separate analyses (LS and SLS), producing models identical to those fitted on complete data. ${ }^{42}$ Within E- DataSHIELD, the limited summary statistics obtained from the separate analyses are transferred by email and then summed within each iteration of the reweighted least squares method. The combined result is then returned, and the process repeated until model convergence is achieved (ie, when results are obtained identical to those which would have resulted from analyses of pooled data). ${ }^{43}$

Poisson regression was used to compare age and sexstandardised all-cause mortality rates between Scotland and England and Wales, and then, separately, between Glasgow and Liverpool and Manchester. Models were run adjusting for age and sex only, and then for age, sex, SES and proxies for social capital (religious affiliation, 'living alone'). The full list of independent variables (and their categories) is shown in table 1.

Additional models were run to examine mortality from suicide (including events of undetermined intent, and defined by ICD10 codes X60-X84, Y10-Y34) for Scotland versus England and Wales only (due to the small number of outcomes).

Data were prepared using Stata 13 and E-DataSHIELD model fitting was undertaken using $R$ routines available as a source file. $^{44}$

\section{RESULTS}

Some $22.5 \%$ of the Scottish sample stated in 2001 they had no religious affiliation, compared with $12 \%$ of those living in England and Wales (table 1). The equivalent figures for Glasgow, Liverpool and Manchester were, respectively, 20\%, $6 \%$ and $14 \%$.

Table 2 summarises the main sets of models. Adjusting for age and gender only, mortality was $24 \%$ higher (incidence rate ratio (IRR) $1.24,95 \%$ CIs 1.22 to 1.25 ) in Scotland than in England and Wales. After adjustment for housing tenure and car ownership, the excess reduced to $13 \%$ (a reduction of $46 \%$ ). The inclusion of religious affiliation did not reduce the IRR further. Unlike religion, 'living alone' was significant in the model (at $\mathrm{p}<0.05$ level), although it did not reduce the overall IRR for Scottish residents. After additional adjustment for educational attainment and economic activity, that excess fell further to $9 \%$ (IRR $1.09,95 \%$ CI 1.06 to 1.12 ).
The results for Glasgow compared with Liverpool and Manchester followed a similar pattern, although the excess mortality was considerably higher. After adjustment for age and gender only, mortality was $34 \%$ higher in the Scottish city. Adjusting for housing tenure and car ownership reduced the excess to $26 \%$ (IRR $1.26,95 \%$ CI 1.11 to 1.43 ), a reduction of $24 \%$. Religious affiliation and 'living alone' did not attenuate the higher mortality further.

Table 3 displays the full, final models. This shows expected higher risks of mortality for particular sections of the population, for example, men compared with women, older compared with youngest, renters compared with home owners. Although it did not reduce the level of excess mortality in Scotland, in the three country model only, those 'living alone' were associated with $11 \%$ higher risk of mortality in the period compared with those not 'living alone'.

Table 4 presents the results of the suicide models for Scotland compared with England and Wales. After adjustment for age and gender only, Scottish residents were associated with $\sim 50 \%$ higher risk of mortality from suicide in the period analysed (IRR $1.50,95 \%$ CIs 1.18 to 1.90 ). This was reduced to $33 \%$ (IRR 1.33 , 95\% CI 1.05 to 1.69 ) after inclusion of the housing tenure and car ownership variables. 'Living alone' was associated with a higher risk of suicide than those not 'living alone' (data not shown), but as table 4 shows, this did not impact on the overall higher risk of mortality in Scotland. Inclusion of the religion variable only slightly attenuated the IRR for Scotland (from $1.33(95 \%$ CIs 1.05 to 1.69$)$ to 1.30 (95\% CIs 1.02 to 1.66)). Additionally, controlling for economic activity resulted in a further very slight reduction in risk (to 1.28 (95\% CIs 1.00 to 1.64$)$ ).

\section{DISCUSSION}

\section{Overall findings and implications}

The study provides further evidence of the high level of 'excess' mortality risk experienced in Scotland and in its largest city compared with elsewhere Great Britain. Furthermore, it shows that these differences are not due to overall differences in levels of religious affiliation.

\section{Strengths and weaknesses}

The principal strengths of the study lie with the data sources: the combined sample size was in excess of 280000 people and, being derived from census data, obviates the sampling bias associated with population surveys. Furthermore, the longitudinal data allow a testing of the hypothesis that would not have been possible with other, cross-sectional, data. The E-DataSHIELD methodology employed, enabling secure joint analysis of the physically separated data, is the first of its kind within the field, and will pave the way for future pooled analyses of ONS LS and SLS data.

However, the principal weakness of the study also lies with the same data sources. The concept of 'religious social capital' relates to social participation, but the Census asks about religious affiliation rather than participation. This is an important distinction as, clearly, not everyone affiliating themselves with a particular religion will attend regular religious services. Indeed, the notion of religion as a 'badge' rather than necessarily a belief has been highlighted by a number of authors. ${ }^{45-48}$ Other limitations include the fact that the English and Welsh censuses, unlike their Scottish equivalent, do not distinguish between Christian religions, discussed further below.

Additional weaknesses in the study design include limiting outcomes to all-cause and suicide mortality only, and a lack of 
Table 1 Independent variables used in regression analysis (with associated descriptive statistics)

\begin{tabular}{|c|c|c|c|c|c|c|}
\hline Variable & Category & $\begin{array}{l}\text { England and Wales } \\
(n=191304)(100 \%)\end{array}$ & $\begin{array}{l}\text { Scotland } \\
(n=92369)(100 \%)\end{array}$ & $\begin{array}{l}\text { Glasgow } \\
(n=9165)(100 \%)\end{array}$ & $\begin{array}{l}\text { Liverpool } \\
(n=1692)(100 \%)\end{array}$ & $\begin{array}{l}\text { Manchester } \\
(n=1091)(100 \%)\end{array}$ \\
\hline Gender & $\begin{array}{l}\text { Female* } \\
\text { Male }\end{array}$ & $\begin{array}{l}97998(51.2) \\
93306(48.8)\end{array}$ & $\begin{array}{l}48123(52.1) \\
44246(47.9)\end{array}$ & $\begin{array}{l}4900(53.5) \\
4265(46.5)\end{array}$ & $\begin{array}{l}903(53.4) \\
789(46.6)\end{array}$ & $\begin{array}{l}563(51.6) \\
528(48.4)\end{array}$ \\
\hline Age (years) & $\begin{array}{l}35-39 * \\
40-44 \\
45-49 \\
50-54 s \\
55-59 s \\
60-64 s \\
65-69 s \\
70-74 s\end{array}$ & $\begin{array}{l}31413(16.4) \\
27845(14.6) \\
25344(13.3) \\
28387(14.8) \\
23.627(12.4) \\
20018(10.5) \\
18352(9.6) \\
16318(8.5)\end{array}$ & $\begin{array}{c}15075(16.3) \\
14416(15.6) \\
13224(14.3) \\
13298(14.4) \\
11152(12.1) \\
9887(10.7) \\
8679(9.4) \\
6638(7.2)\end{array}$ & $\begin{array}{c}1705(18.6) \\
1560(17.0) \\
1253(13.7) \\
1115(12.2) \\
987(10.8) \\
940(10.3) \\
888(9.7) \\
717(7.8)\end{array}$ & $\begin{array}{l}273(16.1) \\
280(16.6) \\
252(14.9) \\
230(13.6) \\
176(10.4) \\
161(9.5) \\
176(10.4) \\
144(8.5)\end{array}$ & $\begin{array}{l}223(20.4) \\
155(14.2) \\
132(12.1) \\
151(13.8) \\
119(10.9) \\
100(9.2) \\
116(10.6) \\
95(8.7)\end{array}$ \\
\hline Housing tenure & $\begin{array}{l}\text { Owner-occupied* } \\
\text { Private rented } \\
\text { Social rented }\end{array}$ & $\begin{array}{c}156435(81.8) \\
8490(4.4) \\
26379(13.8)\end{array}$ & $\begin{aligned} 69422 & (75.2) \\
2490 & (2.7) \\
20457 & (22.2)\end{aligned}$ & $\begin{array}{c}5607(61.2) \\
230(2.5) \\
3328(36.3)\end{array}$ & $\begin{array}{c}1154(68.2) \\
104(6.2) \\
434(25.7)\end{array}$ & $\begin{aligned} 646 & (59.2) \\
54 & (5.0) \\
391 & (35.8)\end{aligned}$ \\
\hline Access to car/van & $\begin{array}{l}\text { Access* } \\
\text { No access }\end{array}$ & $\begin{array}{r}165112(86.3) \\
26192(13.7)\end{array}$ & $\begin{array}{l}73182(79.2) \\
19187(20.8)\end{array}$ & $\begin{array}{l}5138(56.1) \\
4027(43.9)\end{array}$ & $\begin{array}{r}1136(67.1) \\
556(32.9)\end{array}$ & $\begin{array}{l}735(67.4) \\
356(32.6)\end{array}$ \\
\hline Household & $\begin{array}{l}\text { Not living alone* } \\
\text { Living alone }\end{array}$ & $\begin{array}{r}164431(86.0) \\
26873(14.1)\end{array}$ & $\begin{array}{l}78016(84.5) \\
14353(15.5)\end{array}$ & $\begin{array}{l}6968(76.0) \\
2197(24.0)\end{array}$ & $\begin{array}{r}1364(80.6) \\
328(19.4)\end{array}$ & $\begin{array}{l}846(77.5) \\
245(22.5)\end{array}$ \\
\hline $\begin{array}{l}\text { Religious } \\
\text { affiliation }\end{array}$ & $\begin{array}{l}\text { None* } \\
\text { Christian } \\
\text { Non-Christian }\end{array}$ & $\begin{array}{r}22500(11.8) \\
166271(86.9) \\
2533(1.3)\end{array}$ & $\begin{array}{c}22738(22.5) \\
71157(77.0) \\
474(0.5)\end{array}$ & $\begin{array}{c}1834(20.0) \\
7260(79.2) \\
71(0.8)\end{array}$ & $\begin{aligned} 102 & (6.0) \\
1573 & (93.0) \\
17 & (1.0)\end{aligned}$ & $\begin{array}{c}148(13.6) \\
910(83.4) \\
33(3.0)\end{array}$ \\
\hline $\begin{array}{l}\text { Educational } \\
\text { attainment }\end{array}$ & $\begin{array}{l}\text { No qualification* } \\
\text { Qualifications < NVQ4 } \\
\text { level }\end{array}$ & $\begin{array}{l}70830(37.0) \\
87936(46.0)\end{array}$ & $\begin{array}{l}40215(43.5) \\
30425(32.9)\end{array}$ & $\begin{array}{l}4935(53.9) \\
2539(27.7)\end{array}$ & $\begin{array}{l}851(50.3) \\
657(38.8)\end{array}$ & $\begin{array}{l}548(50.2) \\
378(34.7\end{array}$ \\
\hline & $\begin{array}{l}\text { Qualifications HNC/D } \\
\text { and above }\end{array}$ & $32538(17.0)$ & $21729(23.5)$ & $1691(18.5)$ & $184(10.9)$ & $165(15.1)$ \\
\hline Economic activity & $\begin{array}{l}\text { Employed }^{*} \\
\text { Inactive other } \\
\text { Looking after home/ } \\
\text { family }\end{array}$ & $\begin{array}{c}117194(61.3) \\
4507(2.4) \\
11471(6.0)\end{array}$ & $\begin{array}{c}54330(58.8) \\
2897(3.1) \\
4895(5.3)\end{array}$ & $\begin{array}{c}4294(46.9) \\
479(5.2) \\
574(6.3)\end{array}$ & $\begin{aligned} & 804(47.5) \\
& 73(4.3) \\
& 136(8.0)\end{aligned}$ & $\begin{aligned} 566 & (51.9) \\
41 & (3.8) \\
65 & (6.0)\end{aligned}$ \\
\hline & $\begin{array}{l}\text { Permanently sick } \\
\text { Retired } \\
\text { Unemployed }\end{array}$ & $\begin{array}{rl}12 & 770(6.7) \\
41400 & (21.6) \\
3962 & (2.1)\end{array}$ & $\begin{aligned} 8837 & (9.6) \\
18908 & (20.5) \\
2502 & (2.7)\end{aligned}$ & $\begin{array}{c}1610(17.6) \\
1859(20.3) \\
349(3.8)\end{array}$ & $\begin{array}{c}270(16.0) \\
349(20.6) \\
60(3.6)\end{array}$ & $\begin{aligned} 147 & (13.5) \\
232 & (21.3) \\
40 & (3.7)\end{aligned}$ \\
\hline
\end{tabular}

${ }^{*}$ Reference category.

Source: ONS LS and SLS.

Table 2 Overview of results of the Poisson regression modelling comparing all-cause mortality rates (1) for Scotland compared with England and Wales and (2) Glasgow compared with Liverpool and Manchester

\begin{tabular}{|c|c|c|}
\hline \multirow[b]{3}{*}{ Model } & \multicolumn{2}{|c|}{ Excess mortality (all causes) } \\
\hline & $\begin{array}{l}\text { Scotland vs England } \\
\text { and Wales }\end{array}$ & $\begin{array}{l}\text { Glasgow vs Liverpool } \\
\text { and Manchester }\end{array}$ \\
\hline & $\begin{array}{l}\text { Incidence rate ratio } \\
(95 \% \mathrm{Cls})\end{array}$ & $\begin{array}{l}\text { Incidence rate ratio } \\
\text { (95\% Cls) }\end{array}$ \\
\hline Age+sex & $1.24(1.22$ to 1.25$)$ & 1.34 (1.18 to 1.52$)$ \\
\hline Age+sex+tenure & 1.16 (1.14 to 1.17$)$ & 1.31 (1.15 to 1.49$)$ \\
\hline $\begin{array}{l}\text { Age+sex+tenure+car } \\
\text { ownership }\end{array}$ & 1.13 (1.14 to 1.17$)$ & 1.26 (1.11 to 1.43$)$ \\
\hline $\begin{array}{l}\text { Age+sex+tenure+car } \\
\text { ownership+living alone }\end{array}$ & 1.13 (1.12 to 1.14$)$ & 1.26 (1.11 to 1.44$)$ \\
\hline $\begin{array}{l}\text { Age+sex+tenure+car } \\
\text { ownership+living alone } \\
\text { +religion }\end{array}$ & 1.13 (1.12 to 1.15$)$ & 1.28 (1.13 to 1.46$)$ \\
\hline $\begin{array}{l}\text { Age+sex+tenure+car } \\
\text { ownership+living alone } \\
\text { +religion+education }\end{array}$ & 1.13 (1.12 to 1.14$)$ & 1.29 (1.13 to 1.47$)$ \\
\hline $\begin{array}{l}\text { Age+sex+tenure+car } \\
\text { ownership+living alone } \\
\text { +religion+economic activity }\end{array}$ & 1.09 (1.06 to 1.12$)$ & 1.27 (1.12 to 1.45$)$ \\
\hline
\end{tabular}

Sample aged 35-74 and born (and resident) in Scotland and in the SLS census 2001, or born in England (and resident in England and Wales) and in the LS census 2001. Source: ONS LS and SLS. exploration of potential interactions between independent variables. These could be the focus of extended future analyses.

\section{Relevance to other studies}

Given some of the uncertainties discussed above, it is unclear whether the analyses presented here imply that religious social capital plays no part in explaining Scotland's and Glasgow's high levels of excess mortality, or whether instead inadequacies in measurement mean it may still be relevant.

There is convincing evidence of the role of religious participation in explaining differences in health status between populations. ${ }^{30}$ The causal pathways that those studies suggest are also highly plausible: greater social networks, support and integration; less association with damaging lifestyle factors through 'social regulation'; and increased psychological resources and coping mechanisms. ${ }^{28} 29 \quad 32 \quad 49-53$ Religious participation has also been shown to encourage volunteering, itself a component of broader social participation with known links to better health outcomes. $^{28}{ }^{54}$ It is of potential interest that previously highlighted differences in social capital between Glasgow, Liverpool and Manchester included lower levels of volunteering and religious affiliation in Glasgow. ${ }^{26} 27$

The uncertainty limitations with the census questions on religion are frustrating, as is the inability to distinguish between different Christian religions and to examine suicide mortality at the city level. There is international evidence of lower suicide rates among those of Roman Catholic faith compared with 


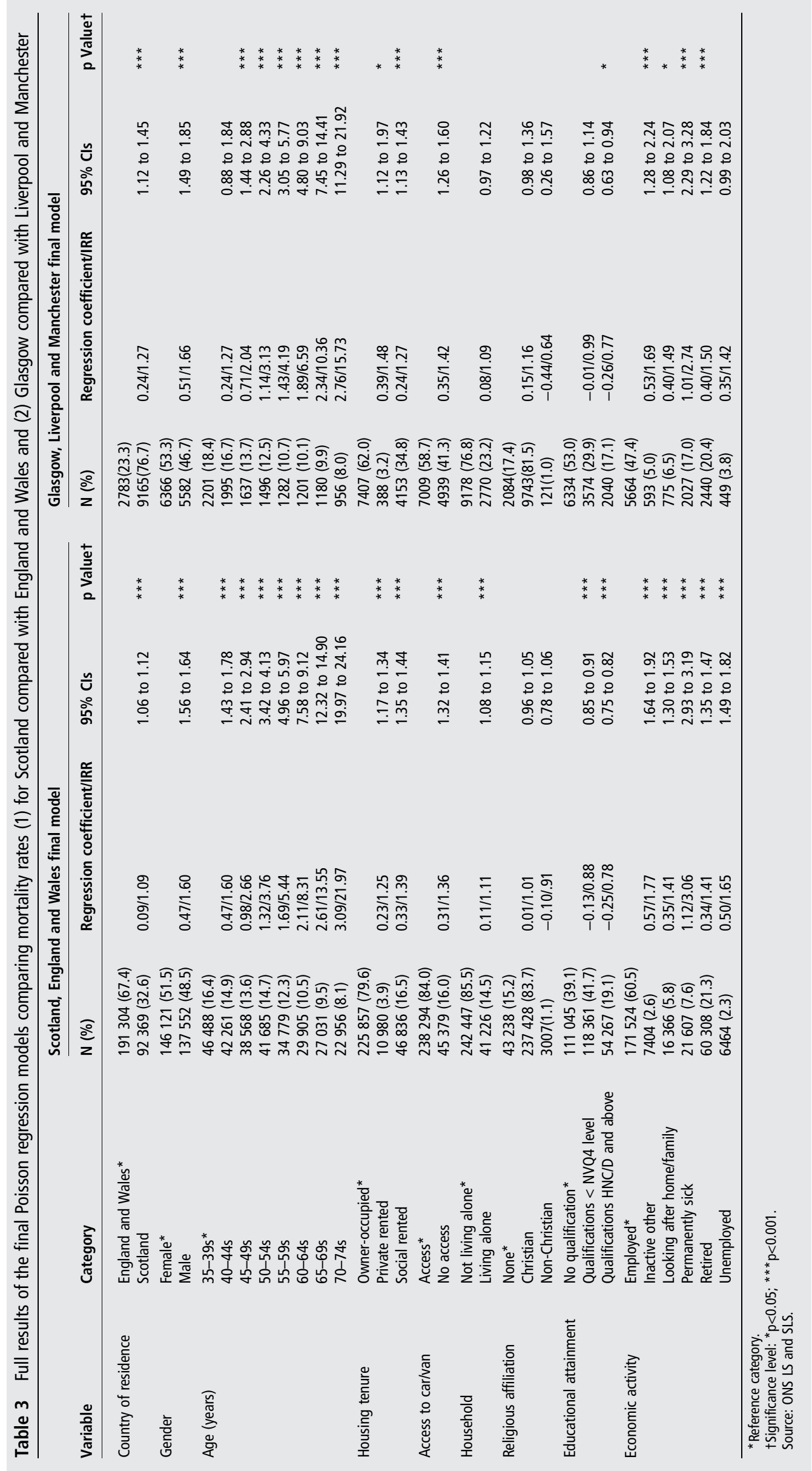


Table 4 Overview of results of the Poisson regression modelling comparing suicide mortality rates for suicide and undetermined intent for Scotland compared with England and Wales

\begin{tabular}{ll}
\hline Model & $\begin{array}{c}\text { Incidence rate ratio }(95 \% \\
\text { CIs) }\end{array}$ \\
\hline Age+sex & $1.50(1.18$ to 1.90$)$ \\
$\begin{array}{l}\text { Age+sex+tenure } \\
\text { Age+sex+tenure+car ownership }\end{array}$ & $1.38(1.09$ to 1.76$)$ \\
$\begin{array}{l}\text { Age+sex+tenure+car ownership+living alone } \\
\text { Age+sex+tenure+car ownership+living alone } \\
\text { +religion }\end{array}$ & $1.33(1.05$ to 1.69$)$ \\
$\begin{array}{l}\text { Age+sex+tenure+car ownership+living alone } \\
\text { +religion+education }\end{array}$ & $1.33(1.05$ to 1.69$)$ \\
$\begin{array}{l}\text { Age+sex+tenure+car ownership+living alone } \\
\text { +religion+economic activity }\end{array}$ & $1.30(1.02$ to 1.65$)$ \\
\hline $\begin{array}{l}\text { Sample aged } 35-74 \text { and born (and resident) in Scotland and in the SLS census 2001, } \\
\text { or born in England (and resident in England and Wales) and in the LS census 2001. } \\
\text { Source: ONS LS and SLS. }\end{array}$
\end{tabular}

Protestants $^{36}$ (something of course also shown historically by Durkheim ${ }^{37}$ ), and Dorling and Gunnell, ${ }^{55}$ commenting on research findings which highlighted lower than expected suicide rates in Liverpool and higher than expected rates in Glasgow, speculated that protective factors relating to religion (specifically high numbers of resident 'practising or believing' Catholics) and social integration might be operating in the English city. Proper investigation of this, however, would require measurement of religious participation rather than affiliation, and robust population-level data in this area are lacking. The few comparable data are from the British Social Attitudes Survey ${ }^{56}$ and the Scottish Social Attitude Survey: ${ }^{57}$ these suggest that among those belonging to a religion, there are similar levels of weekly and monthly attendance at religious services in Scotland compared with all Britain. However, those data also show similar levels of religious affiliation in Scotland and Britain, a finding contradicted by census data covering most of the population (as opposed to surveys of a few thousand individuals with a $\sim 50 \%$ response rate ${ }^{58}$ ). Furthermore, no such data on religious participation are available at the city level.

It is also notable that analysis of a similar census question on religious affiliation included in the Northern Ireland census showed no significant association with mortality from suicide. ${ }^{58}$

That 'living alone' was associated with a higher risk of mortality across the pooled sample (Scotland, England and Wales) corresponds with results of a number of studies examining living arrangements and mortality. ${ }^{59-65}$

The high levels of excess mortality observed in this study are also notable. The $9 \%$ excess for Scotland compared with England and Wales is lower than that observed by Popham and Boyle $^{3}$ for the same age group (probably explained by the incorporation of additional socioeconomic controls and differences in the sample and length of follow-up period), but similar to that observed for all ages in analyses by Hanlon et al ${ }^{1}$ for $2001(8 \%)$ and Schofield et $a l^{13}$ for 2011 (10\%). The 27\% higher mortality in Glasgow compared with Liverpool and Manchester is also comparable to the analyses based on areabased measures of income deprivation (30\% higher mortality for age $<65$ years). ${ }^{9}$

\section{CONCLUSIONS}

Despite previous evidence of an association between religious participation and mortality, adjustment for differences in stated religion did not impact on high levels of 'excess' mortality in Scotland compared with elsewhere in the UK. However, the extent to which this disproves the theory, or is simply a result of inadequate measurement, remains unclear.

\section{What is already known on this subject}

- High levels of unexplained excess mortality (ie, higher mortality once differences in poverty and deprivation have been taken into account) have been observed for Scotland, and in particular its largest city, Glasgow, in comparison to elsewhere in the UK.

- Religious participation has been shown to be associated with lower mortality.

- Levels of affiliation are lower in Scotland compared with England and Wales, and in Glasgow compared with English comparator cities such as Liverpool and Manchester.

\section{What this study adds}

- Differences in religious affiliation between Scotland and England and Wales, and between Glasgow and the English comparator cities, do not attenuate the higher Scottish mortality risk.

- New E-DataSHIELD methodology has been shown to enable detailed analyses of UK census-based longitudinal data while maintaining high levels of data security and confidentiality.

Acknowledgements The help provided by staff of the Longitudinal Studies Centre - Scotland (LSCS) is acknowledged. The LSCS is supported by the ESRC/IISC, the Scottish Funding Council, the Chief Scientist's Office and the Scottish Government. The authors acknowledge Dr Frank Popham, who graciously provided access to files and programmes from his previous analyses. The authors are responsible for the interpretation of the data. Census output is Crown copyright and is reproduced with the permission of the Controller of HMSO and the Queen's Printer for Scotland. The permission of the Office for National Statistics to use the Longitudinal Study is gratefully acknowledged, as is the help provided by staff of the Centre for Longitudinal Study Information and User Support (CeLSIUS). CeLSIUS is supported by the ESRC Census of Population Programme under project ES/K000365/1. The authors alone are responsible for the interpretation of the data. This work contains statistical data from ONS which is Crown Copyright. The use of the ONS statistical data in this work does not imply the endorsement of the ONS in relation to the interpretation or analysis of the statistical data. This work uses research data sets which may not exactly reproduce National Statistics aggregates.

Contributors DW originally conceived the study. The research questions and analysis plan were agreed by all authors. KR and ZF undertook analyses with support from CD and DW. DW drafted the manuscript. All authors provided substantial critical input to improve the manuscript and all authors approved the final draft.

Funding The analysis was funded by the Glasgow Centre for Population Health. Competing interests None declared.

Provenance and peer review Not commissioned; externally peer reviewed.

\section{REFERENCES}

1 Hanlon P, Lawder RS, Buchanan D, et al. Why is mortality higher in Scotland than in England \& Wales? Decreasing influence of socioeconomic deprivation between 1981 and 2001 supports the existence of a 'Scottish Effect'. J Public Health 2005;27:199-204. 
2 Popham F, Boyle PJ, Norman P. The Scottish excess in mortality compared to the English and Welsh. Is it a country of residence or country of birth excess? Health Place 2010;16:759-62.

3 Popham F, Boyle PJ. Is there a 'Scottish effect' for mortality? Prospective observational study of census linkage studies. J Public Health 2011;33:453-8.

4 Connolly $\mathrm{S}$, Rosato $\mathrm{M}$, Kinnear $\mathrm{H}$, et al. Variation in mortality by country of birth in Northern Ireland: a record linkage study. Health Place 2011;17:801-6.

5 McCartney G, Russ TC, Walsh D, et al. Explaining the excess mortality in Scotland compared with England: pooling of 18 cohort studies. J Epidemio/ Community Health 2015:69:20-7.

6 Mok PL, Leyland AH, Kapur N, et al. Why does Scotland have a higher suicide rate than England? An area-level investigation of health and social factors. J Epidemiol Community Health 2013:67:63-70.

7 Walsh D, Taulbut M, Hanlon P. The aftershock of deindustrialization-trends in mortality in Scotland and other parts of post-industrial Europe. Eur J Public Health 2010;20:58-64.

8 McCartney G, Shipley M, Hart C, et al. Why do males in Scotland die younger than those in England? Evidence from three prospective cohort studies. PLOS ONE 2012;7:e38860.

9 Walsh D, Bendel N, Jones $R$, et al. It's not 'just deprivation': why do equally deprived UK cities experience different health outcomes? Public Health 2010;124:487-95.

10 Graham P, Walsh D, McCartney G. Shipyards and sectarianism: how do mortality and deprivation compare in Glasgow and Belfast? Public Health 2012;126:378-85.

11 Stanners G, Walsh D, McCartney G. Is 'excess' mortality in Glasgow an artefact of measurement? Public Health 2015;129:684-90.

12 McCartney G, Collins C, Walsh D, et al. Why the Scots die younger: synthesizing the evidence. Public Health 2012:126:459-70.

13 Schofield L, Walsh D, Munoz-Arroyo R, et al. Dying younger in Scotland: trends in mortality and deprivation relative to England and Wales, 1981-2011. Health Place 2016;40:106-15.

14 Kawachi I. Social capital and community effects on population and individual health. Ann N Y Acad Sci 1999;896:120-30.

15 Kawachi I, Kennedy BP, Lochner K, et al. Social capital, income inequality, and mortality. Am J Public Health 1997:87:1491-8.

16 Wilkinson RG, Kawachi I, Kennedy BP. Mortality, the social environment, crime and violence. Sociol Health IIIn 1998:20:578-97.

17 Lochner KA, Kawachi I, Brennan RT, et al. Social capital and neighborhood mortality rates in Chicago. Soc Sci Med 2003;56:1797-805.

18 Stuckler D, King L, McKee M. Mass privatisation and the post-communist mortality crisis: a cross-national analysis. Lancet 2009:373:399-407.

19 Kennedy B, Kawachi I, Brainerd E. The role of social capital in the Russian mortality crisis. World Dev 1998;26:2029-43.

20 Skrabski A, Kopp M, Kawachi I. Social capital in a changing society: cross sectional associations with middle aged female and male mortality rates. J Epidemiol Community Health 2003:57:114-9.

21 Skrabski A, Kopp M, Kawachi I. Social capital and collective efficacy in Hungary: cross sectional associations with middle aged female and male mortality rates. J Epidemiol Community Health 2004;58:340-5.

22 Hyppä MT, Mäki J. Why do Swedish-speaking Finns have longer active life? An area of social capital research. Health Promot Int 2001;16:55-64.

23 Siahpush M, Singh GK. Social integration and mortality in Australia. Aust N Z J Public Health 1999;23:571-7.

24 Kripper CE, Sapag JC. Social capital and health in Latin America and the Caribbean: a systematic review. Rev Panam Salud Publica 2009:25:162-70.

25 Murayama H, Fujiwara Y, Kawachi I. Social capital and health: a review of prospective multilevel studies. J Epidemiol 2012;22:179-87.

26 Walsh D, McCartney G, McCullough S, et al. Exploring potential reasons for Glasgow's 'excess' mortality: results of a three-city survey of Glasgow, Liverpool and Manchester. Glasgow: Glasgow Centre for Population Health, 2013.

27 Walsh D, McCartney G, McCullough S, et al. Comparing levels of social capital in three northern post-industrial UK cities. Public Health 2015;129:629-38.

28 Maselko J, Hughes C, Cheney R. Religious social capital: its measurement and utility in the study of the social determinants of health. Soc Sci Med 2011;73:759-67.

29 Koenig H, McCullough M, Larson D. Handbook of religion and health. New York: Oxford University Press, 2001.

30 McCullough ME, Hoyt WT, Larson DB, et al. Religious involvement and mortality: a meta-analytic review. Health Psychol 2000;19:211-22.

31 Coruh $\mathrm{B}$, Ayele $\mathrm{H}$, Pugh $\mathrm{M}$, et al. Does religious activity improve health outcomes? A critical review of the recent literature. Explore (NY) 2005;1:186-91.

32 Hummer RA, Ellison CG, Rogers RG, et al. Religious involvement and adult mortality in the United States: review and perspective. South Med 2004;97:1223-30.
33 Hummer RA, Rogers RG, Nam CB, et al. Religious involvement and US adult mortality. Demography 1999;36:273-85.

34 Hill TD, Ellison CG, Burdette AM, et al. Dimensions of religious involvement and leukocyte telomere length. Soc Sci Med 2016;163:168-75.

35 Gearing RE, Lizardi D. Religion and suicide. J Relig Health 2009;48:332-41.

36 Spoerri A, Zwahlen M, Bopp M, et al. Religion and assisted and non-assisted suicide in Switzerland: National Cohort Study. Int J Epidemiol 2010;39:1486-94.

37 Durkheim E. Suicide. New York, NY, USA: The Free Press, 1951.

38 Boyle PJ, Feijten P, Feng Z, et al. Cohort Profile: the Scottish Longitudinal Study (SLS). Int J Epidemiol 2009;38:385-92.

39 Goldring S, Newman J. The ONS Longitudinal Study - a prestigious past and a bright future. Popul Trends 2010;139:4-10.

40 Wolfson M, Wallace SE, Masca N, et al. DataSHIELD: resolving a conflict in contemporary bioscience-performing a pooled analysis of individual-level data without sharing the data. Int J Epidemiol 2010;39:1372-82.

41 Jones EM, Sheehan NA, Gaye A, et al. Combined analysis of correlated data when data cannot be pooled. Stat 2013:2:72-85.

42 Jones E, Sheehan N, Masca N, et al. DataSHIELD-shared individual-level analysis without sharing the data: a biostatistical perspective. Norsk Epidemiologi 2012;21:231-9.

43 Raab GM, Dibben C, Burton P. Running an analysis of combined data when the individual records cannot be combined: practical issues in secure computation. Statistical Data Confidentiality Work Session. UNECE, October 2015.

44 Raab G, Ralston K. E-DataSHIELD: E-mail Data Aggregation Through Anonymous Summary-statistics from Harmonized Individual Level Databases. Scottish Longitudinal Study Working Paper, 2015.

45 Nicolet $S$, Tresch A. Changing religiosity, changing politics? The influence of 'belonging' and 'believing' on political attitudes in Switzerland. Polit Relig 2009:2:76-99.

46 Pollack D, Pickel G. Religious individualism or secularism? Testing hypotheses of religious change-the case of Eastern and Western Germany. Br J Sociol 2007;58:603-32

47 Davie G. Religion in Britain since 1945: believing without belonging. Oxford, UK: Blackwell, 1994

48 Davie G. Religion in modern Europe. Oxford, UK: Oxford University Press, 2000.

49 Ellison CG, Levin JS. The religion-health connection: evidence, theory, and future directions. Health Educ Behav 1998:25:700-20.

50 Pargament KL. The psychology of religion and coping. Theory, research, practice. New York, NY, USA: The Guilford Press, 1997.

51 Jonker L, Greeff AP. Resilience factors in families living with people with mental illnesses. J Community Psychol 2009;37:859-73.

52 Gall TL, Charbonneau C, Clarke NH, et al. Understanding the nature and role of spirituality in relation to coping and health: a conceptual framework. Can Psychol 2005:46:88-104.

53 Borgonovi F. Doing well by doing good. The relationship between formal volunteering and self-reported health and happiness. Soc Sci Med 2008;66:2321-34.

54 Jenkinson $\mathrm{CE}$, Dickens $\mathrm{AP}$, Jones $\mathrm{K}$, et al. Is volunteering a public health intervention? A systematic review and meta-analysis of the health and survival of volunteers. BMC Public Health 2013:13:773.

55 Dorling D, Gunnell D. Suicide: the spatial and social components of despair in Britain 1980-2000. Trans Inst Br Geogr 2003:28:442-60.

56 Park A, Clery E, Crtice J, et al. eds. British social attitudes 28. London: SAGE Publications, 2012.

57 Scottish Social Attitudes Survey data/website. http://www.scotcen.org.uk/media/ 1133114/SSA-Religion_tables.pdf (accessed Dec 2016).

58 O'Reilly D, Rosato M. Religion and the risk of suicide: longitudinal study of over 1 million people. Br J Psychiatry 2015;206:466-70.

59 Ben-Shlomo Y, Davey Smith G, Shipley M, et al. Magnitude and causes of mortality differences between married and unmarried men. J Epidemiol Community Health 1993;47:200-5

60 Helsing KJ, Comstock GW, Szklo M. Causes of death in a widowed population. Am J Epidemiol 1982;116:524-32.

61 House JS, Robbins C, Metzner HL. The association of social relationships and activities with mortality: prospective evidence from the Tecumseh community health study. Am J Epidemiol 1982;116:123-40.

62 Koskenvuo M, Kaprio J, Kesaniemi A, et al. Differences in mortality from ischaemic heart disease by marital status and social class. J Chronic Dis 1980;33:95-106.

63 Seeman TE, Kaplan GA, Knudsen L, et al. Social network ties and mortality among the elderly in the Alameda county study. Am J Epidemiol 1987:126:714-23.

64 Berkman LF, Syme SL. Social networks, host resistance and mortality: a nine-year follow-up of Alameda County residents. Am J Epidemiol 1979;109:186-204.

65 Hajdu P, McKee M, Bojan F. Changes in premature mortality differentials by marital status in Hungary and England and Wales. Eur J Public Health 1995:5:259-64. 